THE EUROPEAN JOURNAL OF LIFE WRITING VOLUME VII(2018)CP39-CP44

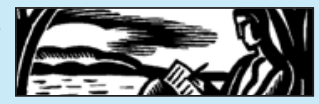

\title{
Philippe Lejeune and the Spirit of May 1968
}

\author{
Jeremy D. Popkin
}

Fifty years ago, France was shaken by a peaceful mass movement, the "events" of May 1968. Millions of students and workers occupied classrooms and factories, demanding a more open, less hierarchical society with greater opportunities for self-expression. Philippe Lejeune, who was then a young assistant professor at the university of Lyon, did not play a major role in the protests, but the movement encouraged him to abandon the conventional academic dissertation he had been writing and to devote himself instead to the study of a topic that fascinated him, the literature of autobiography. ${ }^{1}$ Now, as we look back at what Lejeune has accomplished in his remarkable career, it seems to me that, in spite of his doubts about the movement at the time, he is one of those whose work has best embodied the spirit of May 1968. He has challenged the rigid classifications that condemned autobiography to a marginal literary status and excluded diary-writing from the definition of literature. Equally remarkably, however, he has also devoted much of his time and energy to breaking down the barriers between the academic study of writing, in all its forms, and the broader public and creating a democratic atmosphere in which ordinary people can be recognized, not just as readers but as writers and critics. In the forums in which he loves to participate, something of the free-wheeling spirit of the May events lives on.

When I think of my friend Philippe Lejeune, the memories that come to mind are of watching him flash his ready smile and deploy his wicked sense of humor to put an audience at ease and assure them that he is not just there to lecture, but that he is genuinely interested in what others have to say. Particularly in France, where academics often form part of an elite that tends to radiate a sense of superiority to the majority of 
the population, Lejeune's willingness to go anywhere and talk to anyone about his subject is exceptional. One of the most important of Lejeune's convictions is that writing about the self is a practice that is not and should not be reserved only for authors with literary aspirations. Few members of any society will ever write texts that will be canonized as "literature," but far more will write something or other about their own experiences, and "ordinary" people have important things to say about the meaning of such exercises in life-writing. Lejeune has not only written about these themes: he has also dedicated much of his time and energy to encouraging his fellow-citizens to engage in life-writing, to be willing to share their efforts and their enthusiasm for the practice, and to ensure the preservation and accessibility of such productions.

Like most life-writing scholars, I first encountered Philippe Lejeune through his writings. In the early 1990s, I had begun to take an interest in the autobiographical publications of my fellow historians, and it did not take me long to come across Lejeune's essay on "Le pacte autobiographique" and to recognize the stimulating perspectives it offered on the subject. Since my "day job" as a scholar of French history frequently took me to Paris, I wrote to ask if I could meet him on one of my visits. He duly invited me to his office at the unprepossessing campus of Villetaneuse, in the northern suburbs of the city, and a friendship was born. Over the years, both of us have changed our interests: Lejeune has gone from studying autobiographies to focus on diaries, and I turned from the study of the French press and from my work on historians' autobiographies to an interest in the Haitian Revolution. Nevertheless, I have remained interested in Lejeune's work. Together with a Canadian colleague, Julie Rak, I worked with Lejeune to put together On Diary, a volume of his essays on diary-writing translated into English, which appeared in 2009, and an reunion with him is always a high point of my visits to France. ${ }^{2}$

One of the most memorable aspects of my friendship with Philippe Lejeune has been the opportunity it has given me to see him in action at some of the meetings of the remarkable organization he helped to form, the Association pour l'autobiographie or APA. To be sure, Lejeune has participated in numerous academic meetings and in no way turns his back on such scholarly gatherings. He and I met at several conferences of the IABA (International Auto/Biography Association), although he eventually became frustrated by the increasingly one-sided Anglophone character of that organization's proceedings and even those of its offshoot, the European Auto/Biography Association. In 2005, I had the privilege of attending a remarkable autobiography-studies conference at Yale University, where Lejeune had once been a French exchange student, and listening to a discussion among the three "founding fathers" of the field, 
James Olney, Paul John Eakin and Lejeune, which was probably the last time they were gathered around a single table. But the APA, which has been one of Lejeune's major preoccupations for the past quarter century, is something quite different from these academic venues and represents one of Lejeune's most original contributions to the understanding of life-writing.

Despite its name, the Association pour l'Autobiographie grew out of Lejeune's shift to the study of diaries in the mid-1980s. Earlier scholarly literature on this genre looked only at the published journals of recognized authors; Lejeune wanted to study it as "a life practice and a writing practice," with attention both to the writings of ordinary people and to the material form of the documents. His new investigations resulted in several publications, including 'Cher Cahier' (1989), in which forty-seven French diarists who had responded to his classified advertisement in the Magazine littéraire described their own journal-writing activities, and Le Moi des demoiselles (1993), a study of nineteenth-century girls' diaries, and in an academic conference that he organized. ${ }^{3}$ By this time, however, Lejeune had come to recognize the need to respond to an interest in diary-writing that went well beyond academic circles. It is hardly possible to improve on Lejeune's own description of how his published appeals to people who might have their ancestors' nineteenth-century autobiographical manuscripts led him into this adventure: "I got a number of positive answers, but also several strange letters. These said: 'Sir, I am writing to inform you that I don't possess any nineteenth century manuscripts.' Then, after a few embarrassed sentences, they came to the point: 'But I happen to have something which, however, might be of some interest to you.' Of course, as you have already guessed, that something was the autobiography or diary of my correspondent who went on, apologetically: 'I know I am wrong, I am not a nineteenth-century person, but....'"

Thinking about these correspondents' letters, Lejeune realized that they were facing a real problem. In contrast to the United States, where local history societies, university libraries and archives and other repositories are often willing to preserve private papers as sources for the history of everyday life, French public archives were much less interested in such materials. At first, Lejeune was uncertain how to respond to these correspondents' appeals. He found a model to follow in 1989, when he learned about an Italian project, the "Archivio Diaristico Nazionale," whose organizers had persuaded the municipality of Pieve Santo Stefano, in Tuscany, to sponsor an annual life-writing competition and to create a repository for the texts submitted. The Italian model inspired the issuing of what the APA's web site describes as "l'appel de 19 juin 1991," proposing the creation of a similar organization in France. Lejeune and his friend Chantal 
Chaveyriat-Dumoulin, the great-granddaughter of one of the women whose diaries Lejeune had written about, persuaded the small French town she came from to house the organization's archive. Ambérieu-enBugey, about thirty miles from Lyon, thus earned the right to proclaim itself France's "ville de l'autobiographie." The town originally donated storage space in its library, "La Grenette," but the collection, which now houses over 3500 items, including unpublished autobiographical manuscripts, diaries, and collections of correspondence, has outgrown those quarters and is now being relocated to the municipal archive. ${ }^{5}$

In addition to creating a depository for life-writing texts, Lejeune also wanted to establish an interactive community that would actually read the donated items and promote interest in life-writing. Thus the Association pour l'Autobiographie, established in November 1991, was from the start much more than an effort at conservation. The members of the APA participate in a number of activities. The organization publishes a triennial magazine, La Faute à Rousseau, and a series of Cahiers de l'APA on particular themes. It holds annual general meetings and organizes a number of smaller programs each year, including writing workshops. Some of the members belong to its reading circles, which deal with new donations to the archive. Each contribution is read by a member of one of the reading groups, who prepares a summary description of it and a sort of review which is discussed with the group and then shared with the author or donor. In this way, a kind of dialogue is established, and each life-writing author who contributes to the APA's collection receives an explicit response to his or her efforts. The reviewer also prepares a summary of the donation that is printed in another APA publication, the Garde-Mémoire, which serves as a descriptive catalogue of the organization's holdings.

I have had the privilege of attending several of the APA's gatherings and contributing several articles to its journal. No one can doubt Philippe Lejeune's importance to the organization. He is its public face in seeking support from public agencies in France and even the European Union, but the APA is not a one-man show. The membership tends to be on the older side and predominantly feminine, but they all share a passion for reading and, in many cases, writing first-person accounts. Few of the participants in these gatherings are academics, but they have thoughtful and imaginative things to say about life-writing. Whereas scholarly conferences tend to be occasions for subjecting life-writing texts to rarified intellectualized analysis, Lejeune has encouraged the participants in the APA to experience them in other ways, by reading them aloud, turning them into stage performances, and putting the writings of ordinary people alongside literary classics such as Rousseau's Confessions. In this way, Lejeune has quietly but effectively used the APA to break down 
the hierarchy that permits ordinary people to write about their lives but reserves the interpretation of the genre to academic specialists.

The APA has been Lejeune's main vehicle for trying to promote public interest in life-writing and to establish these productions of "ordinary" people as part of France's patrimoine or public heritage, worthy of preservation and respect, but he has also pursued other ways to achieve this goal. In 1997, he and another collaborator, Catherine Bogaert, organized a public exhibition of diaries at the municipal library in Lyon. Visitors were struck by the many ways in which diary-writers set their thoughts down on paper, combined them with documents or illustrations, and created objects of genuine aesthetic value. Lejeune and Bogaert were able to extend their project through the publication of an elegant coffee-table volume with color illustrations, Un Journal à Soi. Histoire d'une pratique, published in $2003 .{ }^{6}$ A beautiful object in itself, the volume demonstrates the variety of imaginative ways in which diary writers have created their records of their lives.

There is no doubt that Philippe Lejeune and the APA have helped to make France more conscious of the significance of life-writing. The success of the "grande collecte," an appeal, timed for the commemoration of the hundredth anniversary of the outbreak of the First World War in 2014, for members of the public to donate letters, diaries and unpublished memoirs about that event, reflected a new understanding of the importance of such documents, and the APA organized an important joint meeting with its German homologue, the Deutsche Tagebucharchiv in Emmendingen, on the subject. In recent years, the APA has struggled with rising expenses and declining membership numbers, but, as Lejeune was one of the first to recognize, the spread of the Internet and social media has democratized life-writing practices beyond anything he and the association could have imagined. Through his engagements on behalf of life-writing, both in his publications and his commitment to the creation of a community of life-writing enthusiasts, Philippe Lejeune has had a major role in translating the spirit of May 1968 into a lasting change in French culture.

\section{ABOUT THE AUTHOR}

Jeremy D. Popkin is the William T. Bryan Chair of History at the University of Kentucky in Lexington, Kentucky. Together with Julie Rak of the University of Alberta, he co-edited On Diary, a collection of Philippe Lejeune's essays on personal journals, which was published by the University of Hawai'i Press in 2009. Popkin has also published History, Historians and Autobiography and has contributed several articles to La Faute à Rousseau, the magazine published by L'Association pour l'Autobiographie founded by Lejeune. 


\section{NOTES}

1 For Lejeune's own account of his intellectual itinerary, which makes no overt reference to the May 1968 movement, see Philippe Lejeune, "Itinéraires d'une recherche," in Lejeune, Écrire sa vie. Du pacte au patrimoine autobiographique (Paris: Éditions du Mauconseil, 2015), 11-35.

2 Philippe Lejeune, On Diary, eds. Jeremy D. Popkin and Julie Rak (Honolulu: University of Hawai'i Press, 2009).

3 Philippe Lejeune, ed., 'Cher cahier': Témoignages sur le journal personnel (Paris: Gallimard, 1989); Philippe Lejeune, Le Moi des demoiselles (Paris: Seuil, 1993).

4 Lejeune, "Itinéraires," in Écrire sa vie, 30-1.

5 For a chronology of the APA's development, see "Chronologie de l'APA," in the APA's journal, La Faute à Rousseau, no. 31 (Oct. 2002), pp. 24-29. Up-to-date information about the APA and its activities can be found on the association's web site, autobiographie.sitapa.org.

6 Philippe Lejeune and Catherine Bogaert, Un Journal à Soi. Histoire d'une pratique (Paris: Textuel, 2003). 